\title{
Analysis of Cinnamomum Land Suitability and The Conservation Efforts at Eka Karya Bali Botanic Garden
}

\author{
Ayyu Rahayu \\ Eka Karya Bali Botanic Garden - Research Center for Plant Conservation and Botanic Garden, \\ Indonesian Institute of Sciences, Indonesia \\ Jl. Kebun Raya, Candikuning, Baturiti, Tabanan, 82191 \\ *Alamat korespondensi: ayyurahayu08@gmail.com
}

\begin{abstract}
ABSTRAK
Analisis kesesuaian lahan kayu manis dan upaya konservasinya di Kebun Raya Eka Karya Bali

Kayu manis termasuk dalam tumbuhan aromatik yang memiliki nilai ekonomis tinggi. Di Balai Konservasi Tanaman Kebun Raya Eka Karya Bali, koleksi tanaman kayu manis atau Cinnamomum mengalami masalah yaitu kekeringan dan mengalami gugur daun. Tujuan dari penelitian ini adalah untuk mengetahui kelas kesesuaian lahan dan iklim terhadap pertumbuhan koleksi kayu manis. Metode yang digunakan adalah dengan cara mencocokkan data persyaratan tumbuh Cinnamomum dengan data aktual kondisi lahan yang ada di petak penanaman Cinnamomum. Hasil penelitian menunjukkan bahwa tingkat kesesuaian lahan koleksi Cinnamomum adalah S3 (sesuai secara marginal) dengan faktor pembatas berupa kelebihan air. Strategi yang dapat digunakan untuk mengurangi dampak air berlebih adalah dengan melakukan pengelolaan air dan penerapan bahan organik.
\end{abstract}

Kata Kunci: Bahan organik, Layak marjinal, Pengelolaan air

\begin{abstract}
Cinnamomum is an aromatic plant that have high economic value. At the Eka Karya Bali Botanic Garden Plant Conservation Center, the Cinnamomum collection has a problem, that is drought and deciduous leaves. The purpose of this study is to determine the land suitability class and climate of the growth of Cinnamomum collections. The method used is by matching the Cinnamomum growth conditions data to the actual data on the condition of the land. The results show that the level of land suitability for Cinnamomum collections is S3 (marginally suitable) with a limiting factor is water availability. Strategies that can be used to reduce the impact of excess water are water management and the application of organic matter.
\end{abstract}

Keywords: Marginally suitable, Organic matter, Water management

\section{INTRODUCTION}

Indonesia is one of the countries with the largest biodiversity in the world (Widyatmoko, 2019). For plant diversity, Indonesia is estimated to have $25 \%$ of flowering plant species in the world or ranks seventh largest with some species reaching 20,000 species of which $40 \%$ are endemic or native from Indonesia (Kusmana \& Hikmat, 2017). Apart from being carried out in their natural habitat or in their place of origin (in situ), the preservation of plant diversity in Indonesia is also carried out outside their habitat (ex-situ). Risna et al. (2010) state that conservation carried out only in situ carries a very high risk, such as habitat loss due to forest conversion, fire, overuse environmental, pollution and the presence of invasive alien species which in turn can cause decline in local and rare plant populations.

One form of ex-situ conservation site is the botanic garden (Handayani, 2018). Widyatmoko (2019) suggested that the existence of botanic gardens as the main institution of ex situ plant conservation in Indonesia currently has an 
important function in the effort to preserve and utilize plants in Indonesia in a sustainable manner. As one part of the Indonesian Botanic Garden, the Eka Karya Bali Botanic Garden also has the main task of conserving plants, mainly in the dry highlands (Peraturan Kepala LIPI, 2020). In carrying out its duties, the botanic garden always maintains the collection of plants can grow optimally, at a minimum plant habitat management is carried out as close as possible to the habitat of plant origin. In June 2019, one of the Cinnamomum collections of the Eka Karya Bali Botanic Garden experienced a dry and deciduous leaf. This condition is thought to occur due to the incompatibility of the desired habitat of Cinnamomum with the environmental conditions in the Eka Karya Bali Botanic Garden.

The genus Cinnamomum commonly known to has high-value as an aromatic plant. The main product of the cinnamon plant is dry skin which is used as a spice for food flavouring. Along with the rapid development of technology, diversification of products derived from cinnamon plants also increasingly diverse. As stated by Helmalia et al. (2019) that the cinnamon is a multifunctional plant because almost all parts of the plant can be utilized. Cinnamon products in the form of dry skin rolls, powder, shards and stems are used as food flavouring ingredients, beverage mix ingredients, cosmetics. Other products in the form of leaves and twigs are used as an oil (oleoresin) and biopesticides. While wood is used as sawn timber, furniture, charcoal and particle board (Ferry, 2013). In Balinese society, the cinnamon plant is used as a traditional herbal medicine called loloh (Rasna, 2016; Suter, 2015). Based on the results of several studies conducted, cinnamon is proven to contain several compounds such as flavonoids, phenolics and tannins (Kumalasari et al., 2019; Anggriawan et al., 2015). These contents indicate that cinnamon plants have potential as anti-diabetic (Anggriawan et al., 2015), Anticancer (Sufiana dan Harlia, 2014) and as a natural mouthwash (Riani, 2018; Inna et al., 2010). In the Balinese Hindu community, cinnamon plants are also used in the Panca Yadnya ceremony, which is five sacred offerings made sincerely, where the plant parts used are the stem and bark parts (Surata et al., 2015).

The Cinnamon tree (Cinnamomum burmanni (Nees \& T. Nees) Blume) grows well at an altitude of 500-1,500 masl with a sandy-clay texture and loose consistency. This plant requires rain throughout the year with an annual rainfall of
$2,000-2,500 \mathrm{~mm} /$ year with a daily temperature of $19-23^{\circ} \mathrm{C}$ (Yuliarto et al., 2012). Based on that conditions and the potential of Cinnamon tree, it is necessary to conduct a study to assess the land suitability and climate so that in the future, an appropriate land management recommendation can be obtained. As stated by Taslim (2016) that land suitability and climate are an absolute requirement for plants to be able to grow properly in an area.

\section{MATERIALS AND METHODS}

The research was conducted in April to May 2019 in collection plots ( $v a k$ ) number IV.A, X.C and XVIII.E of the Eka Karya Bali Botanic Garden that was located in Candikuning Village, Baturiti District, Tabanan Regency, Bali. The material used in this research is the whole plant collection of Cinnamomum and some land characteristics in Eka Karya Bali Botanic Garden, data collected and obtained through field surveys, as well as laboratory analysis, climate data from the Candikuning climate observation station for the past ten years (20092019). The tools used are pH meter, GPS, clinometer and soil auger to take soil samples and observe soil depth.

Data collection in the field used a purposive sampling technique, which was by finding Cinnamomum tree stands scattered in the plots collection Eka Karya Bali Botanic Garden. Observations were made by observing soil and environmental conditions around Cinnamomum. The parameters of observing soil conditions consist of texture, $\mathrm{pH}$ and effective depth of the soil, while the parameters of environmental conditions consist of topography, slope, altitude, drainage, and surface rock. Land suitability assessment was carried out by matching land characteristics with plant growth requirements. The matching process was used Leibig's minimum law to determine the limiting factor to affect the land suitability class and subclass. Cinnamomum's growth requirements were based on a technical guide evaluating land for agricultural commodities issued by the Indonesian Center for Agricultural Land Research and Development, Ministry of Agriculture (Ritung et al., 2011) (Table 1). The results of land suitability are stated in symbols: i.e. S1 (highly suitable); S2 (moderately suitable), S3 (marginally suitable) and N (not suitable). Evaluation of climate suitability in research is carried out to the unit level, which is a further division based on differences of the limiting factors that influence the management of a sub-class. 
Table 1. Characteristics of land suitability for cinnamon

\begin{tabular}{|c|c|c|c|c|}
\hline \multirow{2}{*}{$\begin{array}{l}\text { Land requirements/land } \\
\text { characteristic }\end{array}$} & \multicolumn{4}{|c|}{ Land suitablity class } \\
\hline & S1 & S2 & S3 & $\mathrm{N}$ \\
\hline \multicolumn{5}{|l|}{ Temperature (tc) } \\
\hline \multirow[t]{2}{*}{ Mean temperature $\left({ }^{\circ} \mathrm{C}\right)$} & $18-22$ & $22-25$ & $25-27$ & $>27$ \\
\hline & & $15-18$ & - & $<15$ \\
\hline \multicolumn{5}{|l|}{ Ketersediaan air (wa) } \\
\hline Total Rainfall (mm/ year) & $2,000-2,500$ & $1,300-2,000$ & $1,000-1,300$ & $<1,000$ \\
\hline Relative Humidity & & $2,500-3,000$ & $3,000-4,000$ & $>4,000$ \\
\hline$(\%)$ & $\leq 75$ & - & - & $>90<70$ \\
\hline Dry month (month) & 1 & - & - & $>1$ \\
\hline \multicolumn{5}{|l|}{ Oxygen availability (oa) } \\
\hline Drainage & good, better & $\begin{array}{c}\text { slightly } \\
\text { hampered }\end{array}$ & $\begin{array}{l}\text { hampered, } \\
\text { slightly fast }\end{array}$ & $\begin{array}{l}\text { very hampered, } \\
\text { fast }\end{array}$ \\
\hline \multicolumn{5}{|l|}{ Rooting condition (rc) } \\
\hline Texture & $\begin{array}{c}\text { SiL, L, SiClL, } \\
\text { SClL, ClL, SCl } \\
<15\end{array}$ & SL & LS & LS \\
\hline Coarse material (\%) & $>100$ & $15-35$ & $35-55$ & $>55$ \\
\hline Soil depth $(\mathrm{cm})$ & & $75-100$ & $50-75$ & $<50$ \\
\hline Peat : & $<100$ & & & \\
\hline Thickness (cm) & saprik & $100-200$ & $200-300$ & $>300$ \\
\hline Maturity & & saprik, hemik & hemik & fibrik \\
\hline \multicolumn{5}{|l|}{ Nutrient retention (nr) } \\
\hline CEC $(\mathrm{cmol})$ & $>16$ & $5-16$ & $<5$ & \\
\hline Base saturation (\%) & $>50$ & $25-50$ & $<25$ & \\
\hline \multirow[t]{2}{*}{$\mathrm{pH} \mathrm{H}_{2} \mathrm{O}$} & $5.0-7.0$ & $4.0-5.0$ & $<4.0$ & \\
\hline & & $7.0-8.0$ & $>8.0$ & \\
\hline Soil Organic Matter (\%) & $>0.4$ & $\leq 0.4$ & & \\
\hline \multicolumn{5}{|l|}{ Nutrient availability (na) } \\
\hline Total nitrogen (\%) & moderate & low & Very low & - \\
\hline $\mathrm{P}_{2} \mathrm{O}_{5}(\mathrm{mg} / 100 \mathrm{~g})$ & moderate & low & Very low & - \\
\hline $\mathrm{K}_{2} \mathrm{O}(\mathrm{mg} / 100 \mathrm{~g})$ & high & moderate & low- very low & - \\
\hline \multicolumn{5}{|l|}{ Toxicity (xc) } \\
\hline Salinity (dS/m) & $<5$ & $5-8$ & $8-10$ & $>10$ \\
\hline \multicolumn{5}{|l|}{ Sodicity (xn) } \\
\hline Alkalinity / ESP (\%) & $<10$ & $10-15$ & $15-20$ & $>20$ \\
\hline \multicolumn{5}{|l|}{ Erosion hazard (eh) } \\
\hline Slope (\%) & $<8$ & $8-15$ & $15-40$ & $>40$ \\
\hline Erosion & Very light & $\begin{array}{l}\text { Light - } \\
\text { moderate }\end{array}$ & heavy & Very heavy \\
\hline \multicolumn{5}{|l|}{ Flood hazard (fh) } \\
\hline Flood height & - & - & 25 & $>25$ \\
\hline Long flood & - & - & $<7$ & $\geq 7$ \\
\hline \multicolumn{5}{|l|}{ Land preparation (lp) } \\
\hline Surfaces stoniness (\%) & $<5$ & $5-15$ & $15-40$ & $>40$ \\
\hline Surfaces outcrops (\%) & $<5$ & $5-15$ & $15-25$ & $>25$ \\
\hline
\end{tabular}




\section{RESULTS AND DISCUSSION}

\section{Cinnamomum spp. Collection of Eka Karya Bali Botanic Garden}

Eka Karya Bali Botanic Garden has plant collection totalled 2,417 plant species with more than 22 thousand specimens spread over an area of 157.5 Ha. Based on catalogue data of March 2020, Eka Karya Bali Botanic Garden has 8 species of Cinnamomum which are spread in 36 collection numbers with a total of 105 individual specimens. Species of Cinnamomum that have been collected by Eka Karya Bali Botanic Garden include Cinnamomum burmanni (Nees \& T.Nees) Blume (7 collection numbers), Cinnamomum camphora (L.) J.Presl (2 collection numbers), Cinnamomum cassia (L.) J.Presl (5 collection numbers), Cinnamomum iners Reinw.ex Blume (1 collection number), Cinnamomum porrectum (Roxb.) Kosterm (1 collection number), Cinnamomum sintoc Blume (6 collection numbers), Cinnamomum verum J.Presl (3 collection numbers) and Cinnamomum sp. (11 collection numbers). Of the various species of Cinnamomum, Cinnamomum sp. has the largest proportion of $31 \%$ of the total Cinnamomum collection owned by the Eka Karya Bali Botanic Garden, as shown in Figure 1.

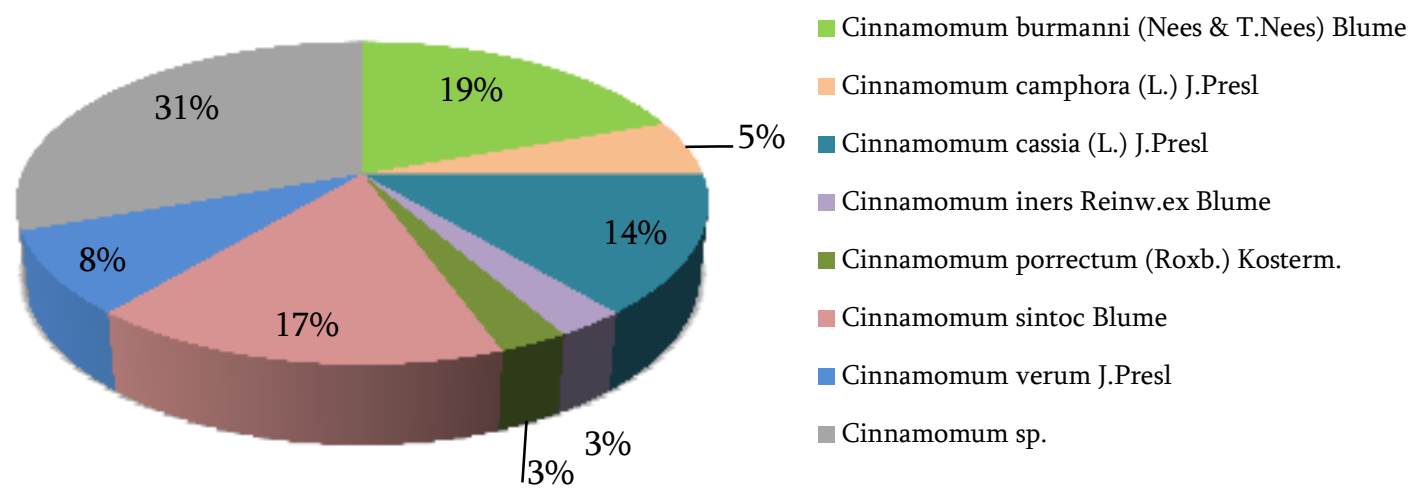

Figure 1. Proportion of the number of collections of Cinnamomum in Eka Karya Bali Botanic Garden.

The Cinnamomum collection in the Eka Karya Bali Botanic Garden is spread over 3 collection plots, that is plot XIV.B which is a special collection plot for the Lauraceae family collection where the Cinnamomum collection is the most widely planted, XC plot or collection plot for the collection of USADA plants (potentially medicinal plants) and plot XIII.E which is a special plot for the Balinese Hindu Traditional Ceremony Plant. Besides being in these three plots, Cinnamomum is also planted on both sides of the road as a pointer plant.

Cinnamomum collection types that have been conserved by the Eka Karya Bali Botanic Garden are mostly obtained from the results of plant exploration activities carried out in various regions of eastern Indonesia. These areas include Sulawesi (Bitung, Enrekang, Tana Toraja, Kendari, North Kolaka and Bone Bolango), East Sumba, Lombok (West Lombok and East Lombok), Kalimantan (Nunukan and Malinau) and in various areas on the island of Bali (Tabanan, Buleleng, Karangasem and Bangli). Apart from exploration activities, the Cinnamomum collection was also obtained from the results of propagation carried out by the Eka Karya Bali Botanic Garden Nursery Unit and donations from the Bogor Botanic Garden.

\section{Climatic Conditions}

Climatic conditions in the study area are based on the acquisition of climate data from the Climate Observation Station in Candikuning Village for the past ten years (2009-2019) as presented in Table 2. The amount of rainfall is calculated by adding up the rainfall in a year then the average calculation is done for ten years. Furthermore, the data is classified into the Schmitdh - Ferguson climate criteria which classify the climate based on the average number of dry months and wet months. Based on the climate classification, the study area has one dry month and eight wet months. So the research area is included in the type A climate classification with a Quotient (Q) value of 0.125. This condition indicates that the study area has a very wet climate. 
Table 2. Average monthly climatic conditions in the study area over the past ten years (2009-2019)

\begin{tabular}{|c|c|c|c|c|c|}
\hline \multirow{2}{*}{ Month } & \multicolumn{4}{|c|}{ Average climate data for 2009-2019 } & \multirow{2}{*}{$\begin{array}{l}\text { Schmidt- } \\
\text { Ferguson climate } \\
\text { criteria }\end{array}$} \\
\hline & Rainfall & Air temperature & Relative humidity & solar radiation & \\
\hline January & 588.55 & 19.58 & 87.44 & 2.3 & $\mathrm{~B}$ \\
\hline February & 595.02 & 19.25 & 90.57 & 2.3 & B \\
\hline March & 436.44 & 19.66 & 88.57 & 1.9 & B \\
\hline April & 322.08 & 19.80 & 88.99 & 2.2 & B \\
\hline May & 187.01 & 19.46 & 88.76 & 1.1 & B \\
\hline June & 71.18 & 18.72 & 90.30 & 2.9 & - \\
\hline July & 69.55 & 18.75 & 85.09 & 3.8 & - \\
\hline August & 56.50 & 18.41 & 89.29 & 4.3 & $\mathrm{~K}$ \\
\hline September & 86.18 & 19.03 & 88.22 & 1.6 & - \\
\hline October & 191.68 & 20.03 & 88.16 & 4.2 & B \\
\hline November & 377.64 & 19.78 & 87.74 & 3.5 & B \\
\hline December & 467.27 & 20.01 & 88.45 & 2.3 & B \\
\hline Total & $3,449.09$ & - & - & - & \\
\hline Average & 287.42 & 19.37 & 88.46 & 2.7 & \\
\hline
\end{tabular}

Schmidt-Ferguson criteria: wet month (B): rainfall more than $100 \mathrm{~mm}$; dry month (K): rainfall less than $60 \mathrm{~mm}$.

Data source: Candikuning Climate Observation Station, Baturiti District, Tabanan

\section{Actual Suitability Land for Cinnamomum Plants}

The results of the land suitability assessment that have been carried out show the land suitability sub-class "S3wa" which means the land in the Eka Karya Bali Botanic Garden is marginally suitable for Cinnamomum plants. Ritung et al. (2011) also explain that marginally suitable land (S3) includes of land that has a weight limiting factor that affects its productivity, and high capital is needed or needs technological input, so there is a need for government or private sector assistance or intervention because farmers are not able to handle it.

High rainfall is the main limiting factor in the development of Cinnamomum in the Eka Karya Bali Botanic Garden. The amount of rainfall in the Eka Karya Bali Botanic Garden area is $3,449 \mathrm{~mm} /$ year, far higher than the amount of rainfall desired by Cinnnamomum of $2,500 \mathrm{~mm} /$ year, as shown in Table 2. The limiting factor in the form of too much rainfall is difficult to fix because it is a natural factor. In accordance with the statement stated by Ritung et al. (2011), that effort to improve limiting factors from nature such as temperature and water availability are difficult to fix because they require very high capital.

The effort that can be made to overcome the high rainfall that gets in the soil is to regulate the water system. This is because changes that may occur due to high rainfall entering the plant growing environment are increased relative humidity and increased soil water content. Both of these have an impact on accelerating the development of pathogens both fungi and bacteria, disruption of the nutritional balance of plants in the soil and the emergence of physical damage to Cinnamomum plants. It is known that that the spread of disease-causing agents through the soil may occur due to flooding, strong winds or transportation of land from areas that are endemic to other areas.

Rainfall limiting factors are difficult to control. However, efforts to reduce the impact due to the large amount of water entering the land must still be made. Surmaini et al. (2011) stated that efforts to overcome these impacts could be made through minimum tillage technology and rain harvesting. Soil cultivation technologies, at least or without tillage, are better able to reduce methane emissions from the soil. Meanwhile, rainwater harvesting aims to accommodate excess water and can also be used to irrigate plants during the dry season. Furthermore, Herlina and Prasetyorini (2020) suggest that farmers usually avoid planting at the beginning of the rainy season, for fear that the plants will receive too much water. This, of course can also be applied by the nursery and maintenance team of the Bali Botanical Garden collection to avoid excess water stress on the plants after being moved from the acclimatization house to the field. 
Table 3. Evaluation of Cinnamomum land suitability at Eka Karya Bali Botanic Garden

\begin{tabular}{|c|c|c|c|}
\hline \multirow{2}{*}{$\begin{array}{l}\text { Quality/ Land Characteristic } \\
\text { Temperature (tc) }\end{array}$} & \multirow[t]{2}{*}{ Data Value } & \multicolumn{2}{|c|}{$\begin{array}{c}\text { Assessment and actual lanc } \\
\text { suitability class }\end{array}$} \\
\hline & & & \\
\hline a. Annual mean temperature & 19.45 & S1 & S1 \\
\hline \multicolumn{4}{|l|}{ Water availability (wa) } \\
\hline b. Mean annual rainfall (mm/ year) & $3,449.09$ & S3 & S3 \\
\hline c. Relative humidity (\%) & 88.94 & S1 & \\
\hline d. Long dry month (month) & 1 & & \\
\hline \multicolumn{4}{|l|}{ Oxygen availability (oa) } \\
\hline e. Drainage & medium & S1 & S1 \\
\hline \multicolumn{4}{|l|}{ Rooting condition (rc) } \\
\hline f. Texture & L, SiL, SL & S1 & S1 \\
\hline g. Coarse material (\%) & $<15$ & S1 & \\
\hline h. Soil depth $(\mathrm{cm})$ & $100 \mathrm{~cm}$ & S1 & \\
\hline \multicolumn{4}{|l|}{ Nutrient retention (nr) } \\
\hline i. $\mathrm{pH}$ & $5.8-7$ & S1 & S1 \\
\hline \multicolumn{4}{|l|}{ Erosion hazard (eh) } \\
\hline j. Slope & $0-15$ & $\mathrm{~S} 2$ & S2 \\
\hline k. Erosion & Slow & S1 & \\
\hline \multicolumn{4}{|l|}{ Flood hazard (fh) } \\
\hline 1. Flood height & - & S1 & S1 \\
\hline $\mathrm{m}$. Long flood & - & S1 & S1 \\
\hline \multicolumn{4}{|l|}{ Land preparation (lp) } \\
\hline n. Surfaces stoniness (\%) & - & S1 & S1 \\
\hline o. Surface outcrops (\%) & - & S1 & $\mathrm{S} 1$ \\
\hline Land Suitability Class & & & S3-wa \\
\hline
\end{tabular}

Notes: $\mathrm{L}=$ loam, $\mathrm{SiL}=$ silt loam, $\mathrm{SL}=$ sandy loam

Management and Conservation Efforts Required for Cinnamon Trees

Cinnamomum collection management at the Eka Karya Bali botanic garden is carried out by the Exploration and Collection Unit, assisted by the registration unit for data recording and the nursery unit for plant propagation. The results of management observation of Cinnamomum collections carried out at the Eka Karya Bali botanic garden are the same as other general plant management, which includes weeding, pest and disease control, fertilization, and routine observation. The most optimal Cinnamomum growth is in plot XIV.B, which is in flat land (0-8\%), open area and sufficient sunlight. The general condition of the Cinnamomum in this plot covering sturdy and upright tree trunks, dense leaves and the absence of pest and disease disorders. This condition is similar to the research Handayani (2018) that studies the management of the Cinnamomum sintoc Blume collection in the Cibodas Botanic Garden. The suboptimal growth of the Cinnamomum collection was seen in plots with insufficient sunlight and shaded areas, such as in X.C and XVIII.E plots. In this plot, the condition of the tree experienced growth problems, such a sparse number of leaves and the presence of brownish-yellow spots on the leaves. Hidayat and Risna (2007) argued that Cinnamomum sintoc Blume need the not too hot area and require a little shade. This condition is different from Cinnamomum which is planted in the Bali Botanic Garden, because almost all shaded Cinnamomum experiences suboptimal growth. Shaded conditions and high humidity in the Eka Karya Bali botanic garden also make the Cinnamomum collection vulnerable to pests and diseases.

Land management activities carried out at the Eka Karya Bali Botanic Garden includes bokor (grass pruning), organic fertilizer application and water management. Cleaning grass is done routinely around the base of the stems of plants. Application of organic matter in the form of compost is given in the plant roots twice times a year and is carried out in the rainy season. In addition to adding plants nutrients, the provision of organic matter aims to 
improve the texture of the soil, which will also affect the increased water holding capacity. This is important to do because the texture of the soil in the planting plot is dominated by sandy texture, wherein the texture of the sandy soil tends difficult to save and hold water. Water management for Cinnamomum collection is carried out on flat land (plot XIV.B). Water management is done by making water drains around collection plots. So that if there is high intensity rain, the water will get in the water drains and not swamp in the soil.

\section{CONCLUSION}

Eka Karya Bali Botanical Garden has S3 land suitability class, which is marginally suitable for the growth and development of cinnamon plants. This is caused by the limiting factor of excess water which comes from the high rainfall that enters to the planting plot. The strategy taken to overcome excess water is carried out by means of water management, in the form of making channels around the planting plot to remove excess water and applying organic matter which aims to improve water management in the soil.

\section{ACKNOWLEDGMENT}

The author cordially thanks Mr. Tuah Malam Bangun and I Nyoman Tiwirya for the discussion of research problems and sampling in the field.

\section{REFERENCES}

Anggriawan, MB, AP Roswiem, and DW Nurcholis. 2015. Potensi ekstrak air dan etanol kulit batang kayu manis padang (Cinnamomum Burmanii) terhadap aktivitas enzim aglukosidase. Journal Kedokteran Yarsi. 23(2): 91-102.

Ferry, Y. 2013. Prospek pengembangan kayu manis (Cinnamomum burmanii L.) di Indonesia. Sirinov. 1(1): 11-20.

Handayani, A. 2018. Ex situ conservation of Cinnamomum sintoc in Cibodas Botanical Garden, West Java. 4(2): 111-114.

Helmalia, AW, Putrid, and A Dirpan. 2019. Potensi rempah-rempah tradisonal sebagai sumber antioksidan alami untuk bahan baku pangan fugsional. Canrea Journal. 2(1): 26-31.

Herlina, N, and A Prasetyorini. 2020. Pengaruh perubahan iklim pada musim tanam dan produktivitas jagung (Zea mays L.) di Kabupaten Malang. Jurnal Ilmu Pertanian Indonesia. 25(1): 118-128.

Hidayat, S, and RA Risna. 2007. Kajian ekologi tumbuhan obat langka di Taman Nasional Bromo Tengger Semeru. Biodiversitas. 8(13): 169-173.

Inna, M, N Atmania, and S Prismasari. 2010. Potential Use of Cinnamomum burmanii essential oil-based chewing gum as oral antibiofilm agent. Journal of Dentistry Indonesia. 17(3): 80-86.

Kumalasari, A, W Handayani, and TA Siswoyo. 2019. Screening fitokimia dan studi aktivitas ekstrak daun sintok (Cinnamomum sintoc Bl.) sebagai antioksidan dan antihiperlipidemia. Berkala Sainstek. 7(1): 24-27.

Kusmana, C, and A Hikmat. 2017. Keanekaragaman hayati flora di Indonesia. Jurnal Pengelolaan Sumberdaya Alam dan Lingkungan. 5(2): 187-198.

Peraturan Kepala LIPI. 2020. Organisasi dan Tata Kerja Balai Konservasi Tumbuhan Kebun Raya Eka Karya Bali. Lembaga Ilmu Pengetahuan Indonesia. Jakarta.

Riani, UY. 2018. Potensi ekstrak kayu manis sebagai obat kumur alami. Seminar Nasional Pendidikan Biologi dan Sauntek III. Pp. 149-154.

Risna, A Rosniati, YWC Kusuma, D Widyatmoko, R Hendrian, and DO Pribadi. 2010. Spesies Prioritas untuk Konservasi Tumbuhan Indonesia. LIPI Press. Jakarta.

Ritung, S, K Nugroho, A Mulyani, and E Suryani. 2011. Petunjuk Teknis Evaluasi Lahan untuk Komoditas Pertanian (Edisi Revisi). Balai Besar Penelitian dan Pengembangan Sumberdaya Lahan Pertanian, Badan Penelitian dan Pengembangan Pertanian.

Sufiana, and Harlia. 2014. Uji aktivitas antioksidan dan sitotoksisitas campuran ekstrak metanol kayu sepang (Caesalpinia sappan L.) dan kulit kayu manis (Cinnamomum burmannii B .). Jurnal Kimia Khatulistiwa. 3(2): 50-55.

Surata, I, I Gata, and I Sudiana. 2015. Studi etnobotanik tanaman upacara hindu bali sebagai upaya pelestarian kearifan lokal. Jurnal Kajian Bali (Journal of Bali Studies. 5(2): 265-284.

Surmaini, E, E Runtunuwu, and I Las. 2011. Upaya sektor pertanian dalam menghadapi 
perubahan iklim. Jurnal Litbang Pertanian. 30(1): 1-7.

Suter, I . 2015. Pangan tradisional: potensi dan prospek pengembangannya. Media Ilmiah Teknologi Pangan. 1(1): 96-109.

Tantra, DK, and IW Rasna. 2016. Implementasi usada sebagai kearifan lokal bali dalam meningkatkan minat masyarakat dan wisatawan mengonsumsi kuliner lokal untuk meningkatkan ekonomi kreatif masyarakat Bali. Seminar Nasional Riset Inovatif Ke-4. Pp. 754-762.

Taslim, I. 2016. Analisis kesesuaian iklim untuk lahan perkebunan di Kabupaten Bone
Bolango 1 Ivan Taslim. Jurnal Bindhe. 1(1): 44-53.

Widyatmoko, D. 2019. Strategi dan inovasi konservasi tumbuhan indonesia untuk pemanfaatan secara berkelanjutan. Seminar Nasional Pendidikan Biologi dan Saintek (SNPBS) Ke-IV. Pp. 1-22.

Yuliarto, FT, LU Khasanah, and RBK Anandito. 2012. Pengaruh ukuran bahan dan metode destilasi (destilasi air dan destilasi uap-air) terhadap kualitas minyak atsiri kulit kayu manis. Jurnal Teknosains Pangan. 1(1): 1223. 